ks. Mieczysław Olszewski

Papieski Wydziat Teologiczny w Warszawie

DOI: $10.15290 /$ std.2017.03.09

\title{
POWIEW DUCHA ŚWIĘTEGO W KOŚCIELE
}

\section{THE BREATH OF THE HOLY SPIRIT IN THE CHURCH}

"The Holy Spirit blows where he wants," that is everyone who believes can receive the gifts of the Holy Spirit. This endowment of the Holy Spirit, ordinary as well as the extraordinary one takes place from the very beginning of the existence of the Church of Christ and became evident in its history, and is being revealed in the formation of various movements at present. One of them is Renewal in the Holy Spirit Movement. It is a special gift of God, a special breath of the Holy Spirit for the today's Church, operating in difficult Times. It is therefore an extraordinary gift for believers and today's world.

Key words: Holy Spirit, communities and movements, Renewal in the Holy Spirit Movement, St. Pope John Paul II.

\section{Wstęp}

Zesłanie Ducha Świętego na Apostołów i rodzący się Kościól był i jest dla wierzących przypływem wielkiej łaski Bożej. Jednak owo spektakularne Zstąpienie Ducha Świętego wydaje się dla wielu dzisiejszych chrześcijan być niemożliwe. Ale ta wątpliwość nie powinna mieć miejsca wśród wierzących już $z$ racji na słowa Pana Jezusa o Duchu Świętym: „Paraklet, Duch Święty, którego Ojciec pośle w moim imieniu, On was wszystkiego nauczy i przypomni wam wszystko, co Ja wam powiedziałem" (J 14, 26) i spełnienie się obietnicy Zesłania Ducha Świętego „Kiedy nadszedł wreszcie dzień Pięćdziesiątnicy, znajdowali się wszyscy razem na tym samym miejscu. Nagle dał się słyszeć z nieba szum, 
jakby uderzenie gwałtownego wichru, i napełnił cały dom, w którym przebywali. Ukazały się im też jakby języki ognia, które się rozdzielały, i na każdym z nich spoczął [jeden]. I wszyscy zostali napełnieni Duchem Świętym, i zaczęli mówić obcymi językami, tak jak im Duch pozwalał mówić” (Dz 2, 1-4). Duch Święty przypominał Apostołom słowa Jezusa i napełniał ich swoimi darami. Owszem, można przy tym stawiać pytanie, czy Duch Święty działał tylko w pierwotnym Kościele, a obecnie już nie działa? Jest to jednak pytanie retoryczne! Duch Święty wciąż działa w Kościele, jest jego duszą, natchnieniem i pomocą. $\mathrm{Na}$ to mamy bardzo wiele świadectw z dziejów Kościoła.

W niniejszym artykule będą ukazane niektóre zjawiska, wydarzenia w Kościele, które dokonują się pod bezpośrednim działaniem Ducha Świętego. Pierwszym takim wydarzeniem było tworzenie się Kościoła jako Ciała Mistycznego Chrystusa, tworzenie jedności wśród wierzących, budowanie z nich wspólnoty. Drugim wydarzeniem, na które chcemy zwrócić uwagę, a którego obecnie jesteśmy świadkami, to spontaniczne powstanie Ruchu Odnowy w Duchu Świętym.

\section{Rola Ducha Świętego w budowaniu wspólnoty Kościoła}

W dziele budowania wspólnoty Kościoła pierwszorzędną rolę odgrywała obecność Ducha Świętego. Jak wspomniano, obecność Ducha Świętego w dziele Zbawienia, które dokonuje się w Kościele, było zapowiedziane przez Pana Jezusa, że Bóg Ojciec pośle Ducha Bożego w Jego imieniu, który wszystkiego nauczy i przypomni wszystko, co On mówił do Apostołów (zob. J 14, 26). A nad tymi, którzy przyjmowali słowo Boże, modlono się, aby mogli otrzymać Ducha Świętego (por. Dz 8 14-17). Bardzo wymowne wydarzenie wylania się Ducha Świętego nawet na pogan, miało miejsce w przypadku nawrócenia setnika Korneliusza. Gdy św. Piotr zaproszony do Korneliusza przemawiał do zebranych, „Duch Święty zstąpił na wszystkich, którzy słuchali nauki” (Dz 10, 44), co wywołało zdumienie wiernych pochodzenia żydowskiego, którzy przybyli z Piotrem, że dar Ducha Świętego wylany został także na pogan (zob. Dz 10, 45). Miłość płynąca z Ducha Świętego zespalała pierwotny Kościól: „Jeden duch i jedno serce ożywiały wszystkich, którzy uwierzyli. Żaden nie nazywał swoim tego, co posiadał, ale wszystko mieli wspólne. Apostołowie z wielką mocą świadczyli o Zmartwychwstaniu Pana Jezusa, a wielka łaska spoczywała na wszystkich. Nikt z nich nie cierpiał niedostatku, bo właściciele pól albo domów sprzedawali je i przynosili pieniądze, składali je u stóp Apostołów. Każdemu też rozdzielano według potrzeby" ( $\mathrm{Dz}$ 4, 32-35). Zarówno w Kościele pierwotnym jak i w dalszych jego dziejach wypełniało się posłannictwo Chrystusa i Ducha Świętego. Katechizm Kościoła Katolickiego podkreśla, że „To wspólne posłanie 
włącza już idących za Chrystusem do Jego komunii z Ojcem i Duchem Świętym: Duch przygotowuje ludzi, uprzedza ich swoją łaską, aby pociągnąć ich do Chrystusa. On ukazuje Zmartwychwstałego Pana, przypomina im Jego słowa i otwiera ich umysły na zrozumienie Jego Śmierci i Jego Zmartwychwstania. Uobecnia im misterium Chrystusa, szczególnie w Eucharystii, aby pojednać ich z Bogiem i doprowadzić do komunii z Nim, aby przynosili „obfity owoc” (J 15, 5. 8. 16. - KKK 737). Katechizm Kościoła Katolickiego ukazuje w tym stwierdzeniu bardzo wyraźnie rolę Ducha Świętego w tworzeniu komunii. Tu chodzi o wspólnotę całego Kościoła, ale też o parafie jako wspólnoty i wspólnoty w obrębie parafii.

\section{Wspólnoty parafii}

Warto dodać, że w ramach parafii istnieją różne grupy, wspólnoty, stowarzyszenia, które dzisiaj są określane słowem „ruchy”. Istnieją różne nazwy grup i form zrzeszania się. Najczęściej używanym obecnie terminem dotyczącym form zrzeszania się jest słowo „ruch”. Słowo to jednak ma szeroki zakres znaczeniowy. Można go ujmować od strony socjologicznej i religijnej. Paweł Załęcki mówi, że można konkretną wspólnotę religijną definiować jako element ruchu społecznego zaliczając ją do grona Nowych Ruchów Religijnych ${ }^{1}$. Rozróżnia on jednak tradycyjne ruchy społeczne i nowe ruchy społeczne. Te pierwsze mogą być określone poprzez wskazanie ich trzech najważniejszych aspektów: aspekt ekonomiczny (np. ruch robotniczy), aspekt stricte polityczny (np. „Solidarność") i aspekt narodowościowy (ruchy nacjonalistyczne i etniczne). Ten autor wskazuje też na pewną prawidłowość istniejącą w tradycyjnych ruchach społecznych dotyczącą przekształcania się (instytucjonalizacji) ruchów tego typu w partie polityczne. Z kolei nowe ruchy społeczne kładą akcent na ich apolityczny charakter. Jako najważniejsze cechy nowych ruchów społecznych wymienia się powszechnie: a) funkcjonowanie w ich ramach uniwersalistycznej zasady działania, myślenia i postrzegania świata przez ich członków; b) słabe zainteresowanie i uznanie za cel ruchu dokonań ekonomicznych czy politycznych zmian szerszej rzeczywistości społecznej².

Nieco odmienne rozumienie „ruchu” wnosi spojrzenie kościelne, ale również o szerszym znaczeniu. Papież Benedykt XVI jeszcze jako kard. Ratzinger, obecny na Światowym Kongresie Ruchów Kościelnych w Rzymie (27-30 V 1998), ukazuje w swoim wystąpieniu powstawanie różnych ruchów w dziejach Kościoła: monastycyzm w III wieku, którego decydującym impulsem było

\footnotetext{
1 P. Załęcki, Wspólnota religijna jako grupa pierwotna, Kraków 1997, s. 21.

2 Ibidem.
} 
pragnienie, aby żyć życiem ewangelicznym, żyć Ewangelią na wzór Apostołów. W wiekach VI-IX ruch monastyczny staje się wielkim ruchem misyjnym (m.in. św. Augustyn z Canterbury), ewangelizacja ludów germańskich w znaczącej mierze przez mnichów pochodzących z Irlandii i Anglii, bracia Cyryl i Metody. A $z ̇$ do dziś pozostaje żywotna i aktywna duchowa siła ewangelicznego ruchu franciszkańskiego i dominikańskiego. Benedykt XVI tak definiuje „ruch”: „Ruchy w większości zapoczątkowane przez osobę charyzmatycznego przywódcy, przybierają kształt konkretnych wspólnot, które na mocy swego pochodzenia wcielają w życie całą Ewangelię i bez wahania uznają w Kościele rację swojego istnienia, bez której nie mogłyby trwać.”

Kardynał Ratzinger pozytywnie wyraził się o nowych ruchach kościelnych odnosząc się do Papieża Jana Pawła II: „W swojej wielkiej encyklice misyjnej Redemptoris missio Ojciec Święty Jan Paweł II napisał:

Wewnątrz Kościoła stoją przed nimi (świeckimi) różne typy służb, funkcji, posług i form ożywiania życia chrześcijańskiego. Pragnę wspomnieć jako nowość, która wyłoniła się w ostatnich czasach w licznych Kościołach, wielki rozwój „ruchów kościelnych", obdarzonych ogromnym dynamizmem misyjnym. Ruchy te - jeśli włączają się z pokorą w życie Kościołów lokalnych i zostają przyjęte serdecznie przez biskupów i kapłanów w strukturach diecezjalnych i parafialnych - stanowią prawdziwy dar Boży dla nowej ewangelizacji, w pluralistycznej wizji form zrzeszania się i działania (RM 72).

Jan Paweł II skierował piękne słowa do uczestników I Kongresu Ruchów Katolickich w Polsce trwającego w dniach 3-4 VI 1994, stanowiące niejako syntezę prac Kongresu, a jednocześnie wyzwanie dla ruchów kościelnych:

Kościół sam jest ruchem. Jest nade wszystko tajemnicą, misterium odwiecznej miłości Ojca: Serca Ojcowskiego, z którego bierze początek posłannictwo (misja) Syna i misja Ducha Świętego. Kościół zrodzony z tego posłannictwa znajduje się in statu missionis. Jest ruchem przenikającym serca i sumienia. Jest ruchem wpisującym się w dzieje człowieka i ludzkich wspólnot. (...) Movimenti w łonie Kościoła, ludu Bożego, wyrażają ów wieloraki ruch, który jest odpowiedzią człowieka na Objawienie, na Ewangelię:

- ruch w kierunku samego Boga żywego, który tak bardzo przybliżył się do człowieka,

- ruch w stronę własnego wnętrza, własnego serca i sumienia, które w spotkaniu z żywym Bogiem odsłania właściwą sobie głębię,

- ruch w stronę ludzi, naszych braci sióstr, których Chrystus stawia na drodze naszego życia,

- ruch w stronę świata, który nieustannie oczekuje na objawienie się synów Bożych w nim.

Ibidem, s. 29 . 
Istotą ruchów w każdym z wymienionych kierunków jest miłość, bowiem „miłość

Boża rozlana jest w sercach naszych przez Ducha Świętego, który nam jest dany”4

Różnorodność ruchów jest wielka. Można jest klasyfikować ze względu na różne kryteria. Henryk Krzysteczko dokonuje następującego podziału: na ruchy ewangelizacyjno-modlitewne, społeczno-religijne i ruchy o charakterze duszpasterskim. Do pierwszych zalicza on m.in. Szensztadzkie Dzieło Rodzin, ruch „Światło-Życie”, Dzieło Maryi - Focolarini, Wspólnota Neokatechumenalna, Charyzmatyczny Ruch Odnowy w Duchu Świętym, Ruch dla Lepszego Świata (Movimento per il Mondo Migliore), Rodziny Nazaretańskie. Wszystkie te ruchy mają charakter formacyjny, zmierzający do wyrobienia w uczestnikach postawy wiary i odpowiedzialności za Kościól5.

Ruchy społeczno-religijne, które mają charakter praktyczny i podejmują działania społeczne w obronie rodziny, w obronie życia dzieci nienarodzonych, upośledzonych umysłowo i ich rodzin, troszczą się o bezdomnych i inne. Są to m.in. Ruch Rodzina Rodzin, Gaudium Vitae, Wiara i Światło ${ }^{6}$, ruch Komunia i Wyzwolenie (Communione e Liberazione), Wspólnota Chleb Życia.

Przykładami ruchów o charakterze duszpasterskim są: Legion Maryi, Pomocnicy Matki Kościoła, Wspólnoty Życia Chrześcijańskiego, Wspólnota Krwi Chrystusa, Czciciele Miłosierdzia Bożego.

Nowe ruchy i wspólnoty kościelne, zwane wspólnotami odnowowymi, charakteryzują się nieco odmiennymi akcentami w wierze niż to ma miejsce u tzw. przeciętnych katolików. Janusz Mariański wymienia trzy akcenty: wiara odnowiona to wiara zakorzeniona raczej w Biblii niż nadbudowana na katechizmie, to wiara chrystocentryczna; w nowych ruchach następuje swoista sakralizacja życia, gdzie nie ma już oddzielnego porządku świeckiego i świętego, życia codziennego i niedzielnego, a to nie znaczy, że wszystko jest sakralne, ale że wszystko może być sakralne, wszystko bowiem jest skierowane ku Bogu; inne rozumienie i przeżywanie Kościoła i sakramentów. Kościół jest mniej instytucją, a bardziej mistycznym Ciałem Jezusa, sakramenty zaś stają się nie tyle wymogiem instytucjonalnym, lecz w większym stopniu osobistym spotkaniem $z$ Jezusem?

$4 \quad$ Cyt. za H. Bolczyk, Działalność ruchów katolickich w Polsce, [w:] Wiosna Ruchów. Materiaty z I Kongresu ruchów katolickich 3-4 czerwca, A. Schulz (opr.), Warszawa [1994], s. 59-60.

$5 \quad$ H. Krzysteczko, W małej grupie religijnej. Wptyw przynależności do małej grupy religijnej na poczucie uczestnictwa w życiu społecznym. Studium pastoralne, Katowice 2003, s. 30 nn.

6 Zob. Orędzie Jana Pawła II z okazji 30-lecia ruchu Wiara i Światto, „Wrocławskie Wiadomości Kościelne”, LIV(2001) nr 2, s. 121-122.

7 J. Mariański, Zmieniająca się religijność $w-i$ poza Kościołem w Polsce, „Wrocławskie Wiadomości Kościelne", LIV(2001) nr 2, s. 225-226. 
Funkcjonowanie, działalność apostolska i formacja w każdym ruchu dokonuje się jednak w poszczególnych małych wspólnotach kościelnych. I to w nich żyje się charyzmatem ruchu, jego ideałami i działa apostolsko, a grupa jest częścią większego ruchu. Dlatego nas interesuje jak funkcjonują małe wspólnoty kościelne, wciąż mając na względzie ich przynależność do szerszego ruchu, działającego we wspólnocie parafialnej.

W tych wszystkich dziełach, w powstawaniu nowych ruchów i wspólnot odczuwa się bezpośrednie działanie Ducha Świętego. Szczególnym przykładem bezpośredniego działania Ducha Świętego jest powstanie i dalsza aktywność w Kościele: Ruchu Odnowy w Duchu Świętym, zwanym także ruchem charyzmatycznym.

\section{0-lecie Ruchu Odnowy w Duchu Świętym}

Początki Odnowy w Duchu Świętym sięgają roku 1967. To już był czas po zakończeniu Soboru Watykańskiego II, który zaowocował nie tylko nowym spojrzeniem na Kościól, ale też zwrócił uwagę na budowanie wspólnoty Kościoła, zwłaszcza w obrębie parafii. W taki sposób deklaruje Konstytucja o Liturgii Świętej Sacrosanctum Concilium:

Ponieważ biskup nie może zawsze i wszędzie osobiście przewodniczyć całej owczarni w swoim Kościele, koniecznie powinien utworzyć grupy wiernych. Najważniejsze z nich są parafie lokalnie zorganizowane pod przewodnictwem duszpasterza zastępującego biskupa. W ten sposób bowiem przedstawiają one widzialny Kościół ustanowiony na całej ziemi. Dlatego w świadomości wiernych i duchowieństwa należy pogłębiać rozumienie życia liturgicznego i jego związku z biskupem oraz rozwijać je w praktyce. Trzeba również dążyć do rozkwitu poczucia wspólnoty parafialnej, zwłaszcza w zbiorowym celebrowaniu niedzielnej Mszy świętej” (KL 42).

Tak więc owo novum przekazane całemu Kościołowi odbiło się szerokim echem wśród wiernych, w dzięki czemu zaczęły się rodzić nowe ruchy i wspólnoty.

Jednym z ruchów kościelnych, które znalazły się w atmosferze soborowej, jest Odnowa w Duchu Świętym, która obchodzi w tym roku (2017) 50-lecie powstania ${ }^{8}$. Warto przypomnieć, jak rodził się ruch Odnowy w Duchu Święty; dostrzegamy bowiem w początkach Ruchu wyraźne działanie Ducha Świętego. Początki Ruchu Odnowy w Duchu Świętym sięgają 1967 roku. Jak pisze Edward O'Connor, dwaj świeccy profesorowie uniwersytetu Duquesne w Pittsburghu

8 Zob. T. Sowa, Obchody 50-lecia Odnowy w Duchu Świętym: wyjaśniał znaczenie reform i odnowy, jaka dokonała się w Kościele w połowie XX stulecia, która opierała się na dwóch filarach - jednym był Sobór Watykański II i spontanicznie rodzący się ruch charyzmatyczny. Zob. https//ekai/warszawa-obchody-50-lecia-odnowy-w-duchu-swietm/?print=1 
w Stanach Zjednoczonych, nie widząc rezultatów w swoich apostolskich poczynaniach, postanowili wzajemnie za siebie się modlić sekwencją do Ducha Świętego ze Mszy św. z uroczystości Zesłania Ducha Świętego. Prawie rok odmawiali tę modlitwę, a gdy spotkali się jeszcze $z$ innymi osobami na dniu skupienia w lutym 1967 roku, wszyscy uczestnicy przeżyli głęboką religijną przemianę doświadczając bardzo osobistego kontaktu z żywym Chrystusem. Pojawily się również u nich, jak w czasach apostolskich, dary charyzmatyczne: dar języków, dar prorokowania, rozpoznawania duchów (zob. 1 Kor 12, 1-11) ${ }^{9}$. Podobne wydarzenia miały miejsce mniej więcej w tym samym czasie na uniwersytecie Notre Dame w poblizu South Bend w stanie Indiana w USA i w innych środowiskach uniwersyteckich w Stanach Zjednoczonych. Ruch charyzmatyczny rozszerzał się tak szybko, że w 1975 roku notowano w Stanach Zjednoczonych 2670 grup modlitewnych. Odnowa w Duchu Świętym dotarła bardzo szybko do wielu krajów poza Stanami Zjednoczonymi, do krajów europejskich, Australii, Nowej Zelandii, do krajów Ameryki Południowej, Japonii, Tajwanu, Filipin, Korei Południowej ${ }^{10}$.

Początek Ruchu Odnowy w Duchu Świętym w Polsce wiąże się z osobą ks. bp. Bronisława Dembowskiego, który po powrocie ze studiów w Stanach Zjednoczonych w 1976 roku, pragnął podzielić się wrażeniami, jakich doznał spotykając się z tym ruchem w USA. Na pierwsze spotkanie dla chętnych przy parafii św. Marcina w Warszawie przyszło około 20 osób. W 1977 roku zaś w Izabelinie zorganizowane zostało pierwsze spotkanie osób, które doświadczyły łaski Odnowy. Byli to ludzie z różnych rejonów Polski: z Poznania, Warszawy, Katowic, Białegostoku. Zainteresowani ruchem Odnowy byli też księża, którzy spotkali się w Izabelinie. Byli to: ks. Bronisław Dembowski, ks. Marian Piątkowski z Poznania, o. Adam Schulz, o. Józef Kozłowski, o. Pietras - jezuici i ks. Andrzej Grefkowicz ${ }^{11}$. Obecnie w Polsce (2017 rok) we wspólnotach Odnowy w Duchu Świętym jest nieco ponad 20 tysięcy stałych członków, natomiast na doroczne spotkania modlitewne Odnowy na Jasnej Górze przybywa nawet kilkaset tysięcy osób ${ }^{12}$. Jest natomiast bardzo wymowne, że z ruchów w ogóle w Polsce wywodzi się ponad 70\% powołań zakonnych i kapłańskich ${ }^{13}$.

9 E. D. O’Connor, Ruch charyzmatyczny w Kościele Katolickim, Warszawa 1984, s. 11.

10 Ibidem, s. 12.

11 Zob. M. Olszewski, Ks. Stanisław Szczepura pierwszym opiekunem Odnowy w Duchu Świętym w Archidiecezji Białostockiej, [w:] W stużbie Kościoła, Z. T. Klimaszewski (red.), Białystok 2011, s. 210.

12 Zob. T. Sowa, Obchody 50-lecia Odnowy, s. 4.

13 J. Święcicki, Ruchy i Stowarzyszenia Katolickie wiosną Kościoła, Niedziela.pl [13.06.2017]. 
Tak więc widzimy zarówno spontaniczność Ruchu Odnowy w Duchu Świętym, ale i jego głębokie zanurzenie się w Bogu, gdy uczestnicy rekolekcji i spotkań przyjmują uroczyście i świadomie Jezusa jako swego Pana, a dzieje się to wszystko w Duchu Świętym. Tak jak pierwsi chrześcijanie otrzymywali charyzmaty do wielbienia Boga i do posługiwania nimi braciom, takich też doświadczeń doznali pierwsi współcześni charyzmatycy czy to w Pittsburghu, czy w Notre Dame, a których doświadczają i dzisiaj uczestnicy grup modlitewnych na całym świecie, zwłaszcza uczestniczący w Rekolekcjach Ewangelizacyjnych Odnowy (REO).

Grupy modlitewne gromadzą się systematycznie na spotkaniach modlitewnych, których głównym elementem jest głośna, żywa modlitwa. Spotkania mają zwykle strukturę otwartą, lecz pewne elementy spotkania powtarzają się: chodzi o zaproszenie Ducha Świętego do prowadzenia spotkania, powszechnie występuje uwielbienie Boga i ten rodzaj modlitwy dominuje w grupach, następnie słuchanie Słowa Bożego, słowa pouczenia, ale częstokroć mają miejsce świadectwa życia. Podczas spotkań modlitewnych ujawniają się charyzmaty. Charyzmaty, nadnaturalne dary Ducha Świętego, udzielane są od wieków różnym osobom dla budowania całej wspólnoty. Do charyzmatów zalicza się m.in. tzw. dary epifanijne, czyli nadzwyczajne: dar języków pojawiający się najczęściej w modlitwie jednoczesnej uczestników, dar tłumaczenia języków, który polega na wyjaśnieniu treści usłyszanego przed chwilą przesłania, dar proroctwa, czy dar uzdrawiania ${ }^{14}$.

Warte podkreślenia są słowa papieża, św. Jana Pawła II, o charyzmatach $z$ adhortacji apostolskiej Christifideles Laici:

Duch Święty, który powierza Kościołowi - Komunii różne posługi, równocześnie ubogaca go w szczególne dary i zdolności, które nazywamy charyzmatami. Mogą one przyjmować najrozmaitsze formy, już to jako wyraz najpełniejszej wolności Ducha, który jest ich dawcą, już to jako odpowiedź na różnorodne wymogi pojawiające się w dziejach Kościoła. [...] Charyzmaty, czy to nadzwyczajne, czy też proste i pokorne, dzięki Duchowi Świętemu, który w nich jest, działają zawsze, pośrednio lub bezpośrednio, dla dobra Kościoła, wnosząc - zgodnie ze swym przeznaczeniem - wkład w budowanie, w powiększenie ludzkiego dobra i w zaspokojenie potrzeb świata (ChL 24).

Dalej Papież odwołując się do Dekretu o apostolstwie świeckich Soboru Watykańskiego II mówi, że:

z przyjęcia tych charyzmatów, nawet zwyczajnych, rodzi się dla każdego wierzącego prawo i obowiązek używania ich w Kościele i w świecie dla dobra ludzi i budowania Kościoła, w wolności Ducha Świętego, który wieje, dokąd chce (J 3, 8), zarazem w zjednoczeniu z braćmi w Chrystusie, zwłaszcza ze swymi pasterzami (DA, 3). 
Słowa kluczowe: Duch Święty, wspólnoty i ruchy, Odnowa w Duchu Świętym, św. Jan Paweł II.

\section{Bibliografia:}

1. Bolczyk H., Działalność ruchów katolickich w Polsce, [w:] Wiosna Ruchów. Materialy z I Kongresu ruchów katolickich 3-4 czerwca, A. Schulz (opr.), Warszawa [1994].

2. Krzysteczko H., W matej grupie religijnej. Wplyw przynależności do małej grupy religijnej na poczucie uczestnictwa w życiu spolecznym. Studium pastoralne, Katowice 2003.

3. Mariański J., Zmieniająca się religijność w - i poza Kościotem w Polsce, „Wrocławskie Wiadomości Kościelne”, LIV(2001) nr 2.

4. Olszewski M., Ks. Stanistaw Szczepura pierwszym opiekunem Odnowy w Duchu Świętym w Archidiecezji Białostockiej, [w:] W stużbie Kościoła, Z. T. Klimaszewski (red.), Białystok 2011, s. 210.

5. Orędzie Jana Pawta II z okazji 30-lecia ruchu Wiara i Światto, „Wrocławskie Wiadomości Kościelne", LIV(2001) nr 2, s. 121-122.

6. O'Connor E. D., Ruch charyzmatyczny w Kościele Katolickim, Warszawa 1984.

7. Sowa T., Obchody 50-lecia Odnowy w Duchu Świętym, https://ekai/ warszawa-obchody-50-lecia-odnowy-w-duchu-swietm/?print $=1$

8. Święcicki J., Ruchy i Stowarzyszenia Katolickie wiosna Kościoła, Niedziela.pl [13.06.2017].

9. Załęcki P., Wspólnota religijna jako grupa pierwotna, Kraków 1997. 